\title{
Mechanisms of Adaptation of Trees and Shrubs to Dry and Hot Environments
}

\author{
Giovanbattista de Dato ${ }^{1}$ (D) and Eustaquio Gil-Pelegrín ${ }^{2, *(D)}$ \\ 1 Research Centre for Forestry and Wood, Council for Agricultural Research and Economics (CREA), \\ 52100 Arezzo, Italy; giovanbattista.dedato@crea.gov.it \\ 2 Agrifood Research and Technology Centre of Aragon, Unidad de Recursos Forestales, 50059 Zaragoza, Spain \\ * Correspondence: eustaquio.gil@gmail.com
}

Citation: de Dato, G.; Gil-Pelegrín, E. Mechanisms of Adaptation of Trees and Shrubs to Dry and Hot Environments. Forests 2021, 12, 1080. https://doi.org/10.3390/f12081080

Received: 4 August 2021

Accepted: 6 August 2021

Published: 13 August 2021

Publisher's Note: MDPI stays neutral with regard to jurisdictional claims in published maps and institutional affiliations.

Copyright: (c) 2021 by the authors. Licensee MDPI, Basel, Switzerland. This article is an open access article distributed under the terms and conditions of the Creative Commons Attribution (CC BY) license (https:// creativecommons.org/licenses/by/ $4.0 /)$.
This Special Issue, focused on the study of different "Mechanisms of Adaptation of Trees and Shrubs to Dry and Hot Environments", would be a humble tribute to A.F.W. Schimper, author of "Plant Geography on a Physiological Basis", published in English in 1903 by Clarendon Press, Oxford, (UK). The study of functional adaptations of plants from a mechanistic point of view is the aim of so-called plant physiological ecology, or plant ecophysiology, the section to which this issue belongs. Many papers have been published concerning mechanisms to cope with drought as a basic resource for plant life. However, if we look back and read that excellent geobotanical synthesis, with exhaustive and still-valid physiological and anatomical explanations of the adaptive mechanisms of plants to cope with very different environmental factors, most of the basic ideas about plants living under extreme conditions are there found. As such, the papers in this special issue should be considered as bricks for a building whose foundations were laid by authors such as Schimper and contemporaries.

As an example, in the very first ages of "Plant Geography on a Physiological Basis", the author literally stated that "No factor affecting plant life is so thoroughly clear as the influence of water". This sentence by itself could justify this or any other volume concerning water stress and plant response. However, understanding how plants survive in dry environments is not exclusively the aim of this issue. In fact, most areas of the world can be defined as "cold dry areas" during the whole year or a long winter period. Frozen soils or soil at temperatures just above the freezing point impede or limit the water uptake by roots, a circumstance that limits the survival or growth of woody plants in cold steppes and in alpine or polar areas. In fact, the substitution of forests by grasslands in the alpine or arctic timberline has been widely attributed to this fact. This "physiological drought" induced by the state or the temperature of the water in the soil was already included in Schimper's book.

As reflected in the title of the issue, its focus is to offer more information concerning many trees and shrubs that survive in areas under severe combinations of low precipitation and high temperatures, both throughout the year (as in many arid lands permanently under high atmospheric pressure) and in the form of a dry season (as in areas under a Mediterranean-type climate). In fact, the scarcity of water for optimal plant life is not only a matter of low precipitation, but the consequence of an imbalance between water inputs and outputs. As such, similar annual precipitation values can correspond to humid temperate climates or dry Mediterranean ones, where high summer temperatures coincide with the temperature maximum.

Further, there is the balance between water inputs via precipitation $(\mathrm{P})$ and water outputs via direct evaporation and plant transpiration (potential evapotranpiration or PET). As reviewed by Peguero-Pina et al. [1] in this issue, many indexes have been proposed since the early 20th century to incorporate this balance in climatology. The first proposal solely considered, in different ways, the quotient between precipitation and temperature 
(e.g., Lang, Köppen or De Martonne indexes). These are still used to establish an ecological comparison due to the easy access to the main parameters involved. However, it is widely accepted that a ratio between $\mathrm{P}$ and PET is the best way to quantify the aridity of a territory. As PET is influenced by the amount of solar radiation, the air temperature and the vapor pressure deficit of the atmosphere, areas under climatic circumstances prone to induce hot and dry air with a high heat load due to solar radiation are clear candidates to be arid the whole year round or, as indicated above for Mediterranean areas, during a seasonal period. It has been suggested that more than $40 \%$ of the Earth can be considered "drylands", according to the value of the ratio P/PET, known as "Aridity Index" [1]. Any change in the climate toward higher temperatures, besides causing dangerous soil degradation that would reduce the water reserves for plants, can increase this percentage.

It is obvious that subtropical deserts, at ca. $30^{\circ}$ north and south latitude, and with extreme values for the Aridity Index, are the better example of dryland, with scarce vegetation but offering amazing examples of adaptations. We can again incorporate Schimper's view about the ecological conditions there. He clearly stated that "the vegetative periods depend on the heat, which increases the injurious effects of drought and therefore brings plantlife to a state of rest at the time of its maximum. The atmospheric dryness acts in the same manner as the heat, and is usually much greater in deserts than in woodland and grassland districts".

The high pressures induced by the downward movement of the Hadley cells are the reason for high atmospheric stability and, consequently, low precipitation and high solar radiation. The "rain shadow" induced by high mountain ranges also influences the climate leeward, generating deserts at latitudes far from those before mentioned. Examples of such deserts can be found in the Americas, with the Sonoran Desert as a paradigm of such landscapes. The high atmospheric pressure during summer, influenced by the position of the Hadley cells during this period, also influences the climate in the Mediterranean areas during the already mentioned period of summer aridity. Some interesting adaptations can be found in the vegetation covering these territories, as a response to the quite-similar aridity, although compensated during the year, which can be registered in deserts. During this Mediterranean summer, woodlands and shrublands are affected by a period of aridity which structurally limits and defines the phenology and physiology of the woody plant species there living [1]. In fact, the limitations for plant growth by water deficit during the summer are the genuine essence of Mediterranean-type climates, with convergent vegetation worldwide.

Dry and hot atmospheres, with a high vapor pressure deficit (VPD), impose themselves conditions of extreme gradients between the plant leaf and the surrounding air. In order to save water, plants close stomata at the expense of carbon gain. This response may be soil mediated, as is revealed by a predictive relationship between the plant water potential at predawn (assumed to be close or equal to that in the soil) and the maximal stomatal conductance daily registered in the leaves. However, more and more papers evidence that stomatal closure can also be a direct response to VPD, with interesting differences among species. A high sensitivity to VPD may impede the adequate carbon gain by plant leaves even at relatively high soil water contents, making the air dryness a limiting factor that could explain some limits for the distribution of many species of paramount importance in the Mediterranean areas. The stomatal closure as a way for reducing transpirational water losses can induce another dangerous response in the leaf: extreme overheating. Heat stress negatively influences leaf physiology at very different levels. A temperature range close to $50{ }^{\circ} \mathrm{C}$ has been proposed as a threshold value for $\mathrm{C} 3$ plants [1]. At lower leaf temperatures, a rise in tissue respiration can be expected. High leaf temperature can also affect the properties of the leaf cuticle, inducing a higher water loss through this barrier. Many plants living in drylands, even in deserts, are, in fact, water spenders. This strategy ensures transpiration leaf cooling at the expense of high water loss. In other cases, the development of complex leaves, such as those with deeply lobed margins, has been found to produce better convective leaf cooling even at low air speeds. This morphological response has a negative consequence in the total photosynthetic area used for carbon gain. 
Similarly, altered water availability can change wood properties. This relationship was shown in the paper by Royo-Navascues et al. [2]. They focused on the relevance of the proportion of latewood and earlywood in a Mediterranean conifer species along a climatic gradient, asserting that their ratio reveals a trade-off between efficiency and safety strategy in the growth patterns across the species distribution. In more productive areas, the trees presented a higher earlywood proportion (more efficient for water transport); in more xeric conditions, the latewood proportion increased (more safety to avoid embolisms), implying an adaptation to more frequent drought episodes and a higher capacity of carbon depletion. The timing of water limitation along the seasons, as above explained, can play a pivotal role in controlling growth sensitivity to moisture availability. The increase in the aridity by rapid warming during the transition season (April-June) is inducing clear constraints in the growth of Pinus latteri in lowland areas of northeastern Thailand [3].

Besides the environmental factors, forest management has an impact on controlling water consumption and demand. The study by Marini et al. [4] in different Mediterranean chestnut stands underlines that the stands with the highest competition between shoots and between stumps were the most sensitive to climate parameters, while thinning practice could have a positive effect on productivity.

In the long term, drought events often induce alteration of mortality, recruitment, growth, demographic rates, and species assemblage, driving the ecosystem towards different trajectories $[5,6]$.

In the perspective to restore and create new resilient forests, targets included in several programs at the international level, continuing to investigate tree responses to environmental variables and drier conditions is still fundamental. In fact, at the population level, the adaptation of trees from different parts of the species distribution range can vary significantly, with important implications for the selection of resilient genotypes to be used in breeding and reforestation programs $[7,8]$.

Funding: This research received no external funding.

Conflicts of Interest: The authors declare no conflict of interest.

\section{References}

1. Peguero-Pina, J.J.; Vilagrosa, A.; Alonso-Forn, D.; Ferrio, J.P.; Sancho-Knapik, D.; Gil-Pelegrín, E. Living in Drylands: Functional Adaptations of Trees and Shrubs to Cope with High Temperatures and Water Scarcity. Forests 2020, 11, 1028. [CrossRef]

2. Royo-Navascues, M.; Martinez del Castillo, E.; Serrano-Notivoli, R.; Tejedor, E.; Novak, K.; Luis Alberto Longares, L.A.; Saz, M.A.; De Luis, M. When Density Matters: The Spatial Balance between Early and Latewood. Forests 2020, 11, 818. [CrossRef]

3. Rakthai, S.; Fu, P.-L.; Fan, Z.-X.; Gaire, N.P.; Pumijumnong, N.; Eiadthong, W.; Tangmitcharoen, S. Increased Drought Sensitivity Results in a Declining Tree Growth of Pinus latteri in Northeastern Thailand. Forests 2020, 11, 361. [CrossRef]

4. Marini, F.; Battipaglia, G.; Manetti, M.C.; Corona, P.; Romagnoli, M. Impact of Climate, Stand Growth Parameters, and Management on Isotopic Composition of Tree Rings in Chestnut Coppices. Forests 2019, 10, 1148. [CrossRef]

5. Zou, S.; Zhang, Q.; Zhou, G.; Liu, S.; Chu, G.; Li, R.; Ye, Q.; Zhang, D.; Tang, X.; Liu, J.; et al. Functional Composition Changes of a Subtropical Monsoon Evergreen Broad-Leaved Forest Under Environmental Change. Forests 2020, 11, 191. [CrossRef]

6. Kaewthongrach, R.; Vitasse, Y.; Lamjiak, T.; Chidthaisong, A. Impact of Severe Drought during the Strong 2015/2016 El Nino on the Phenology and Survival of Secondary Dry Dipterocarp Species in Western Thailand. Forests 2019, 10, 967. [CrossRef]

7. San-Eufrasio, B.; Sánchez-Lucas, R.; López-Hidalgo, C.; Guerrero-Sánchez, V.M.; Castillejo, M.Á.; Maldonado-Alconada, A.M.; Jorrín-Novo, J.V.; Rey, M.-D. Responses and Differences in Tolerance to Water Shortage under Climatic Dryness Conditions in Seedlings from Quercus spp. and Andalusian Q. ilex Populations. Forests 2020, 11, 707. [CrossRef]

8. Ghouil, H.; Sancho-Knapik, D.; Ben Mna, A.; Amimi, N.; Ammari, Y.; Escribano, R.; Alonso-Forn, D.; Ferrio, J.P.; Peguero-Pina, J.J.; Gil-Pelegrín, E. Southeastern Rear Edge Populations of Quercus suber L. Showed Two Alternative Strategies to Cope with Water Stress. Forests 2020, 11, 1344. [CrossRef] 